\title{
Can a hotel be ecological?
}

\author{
E. Trocka-Leszczyńska \& J. Jablonska \\ Faculty of Architecture, Wroclaw University of Technology, Poland
}

\begin{abstract}
A hotel is a business and commercial enterprise focusing on gathering maximum income while optimizing costs. Owners try to encourage clients to choose their brand by adding new services, rising up standards, refurbishing and renewing interiors in order to surprise guests with a new design. Constant development of this branch forces its elements to change and transform every day. This aspect is both positive and negative. It brings aliveness to the surroundings but then costs, material and energy usage are high. Certainly, tendencies for building ecological hotels have been found trendy and are used as a marketing element, but can a hotel be truly ecological? Does this expression mean only usage of energy and water saving solutions? Can a network hotel with 900 rooms located in a small mountain town or a very modern object placed next to an old historical church be ecological under any circumstances? Is culture of building important? This article is an attempt to find answers to the aforementioned questions. Mostly Polish hotels have been chosen as a research material for study as we have experienced a large growth in this area since information about EURO 2012 was announced. Among other examples, buildings such as "Hotel Golebieski" in Karpacz, "Scandic", "Tumski" and "Puro" in Wroclaw, "HOT_elarnia" in Puszczykowo will serve as an analysis and a comparative analysis to find what qualities stand for a truly ecological hotel.

Keywords: ecological hotel, ecological solutions, environment friendly policies.
\end{abstract}

\section{Introduction}

Ecology in modern Europe is one of the most important issues both in scientific discussions and in everyday life. Common citizens use energy saving light bulbs, sort waste, save water, and re-think each instance of car use. Architects more often meet investors who ask for designing solar panels on the roofs of their future houses together with recuperation to support their heating system work. 
Local actions are important, nonetheless, it is crucial that large energy consumers and waste producers like industrial and public utility buildings engage in environment friendly initiatives as well. This article is devoted to research this particular issue on the example of city hotels as well as those situated in the country. Studies have shown that also guests are interested in the ecological approach of hotel branches. In 2010 Network Starwood Hotels \& Resorts revealed that $69 \%$ of Polish consumers choose a hotel with regard to its ecofriendly policies. Studies were conducted in six Polish hotels during realization of their own individual program called Zielony Pokój (Eng. Green Room). $[1$, p. 5].

Bärbel Holzberg (in [2, pp. 8-9]) emphasizes that ecological buildings do not necessarily have to be functional and unattractive and Krzechowicz in her article [3, p. 25] presents works of the Australian architect Glenn Murcutt who uses both ecological and economical materials to create realizations that are affordable, environment friendly and become a part of the local landscape. In a number of the studied examples, designers managed to combine care about environment with tasteful architectural solutions. Ewa Gwóźdź [4, p. 98] reminds us that: 'ecology is a science about the structure and functioning of nature with research focusing on interactions between organisms and their environment and also between organisms themselves'. If we relate this definition to the building, we can study relations within built environment, between buildings, their users and the natural environment.

\section{Research and method}

The term 'ecological' was considered on two levels. Firstly, literal understanding of this word was assumed and studies were focused on problems of creating a truly environment-friendly hotel with solutions aiming at obtaining most reasonable parameters within an economical aspect. Secondly, attention was drawn towards cultural sensitivity. This part was devoted to consideration of design methods and materials used to blend new hotel buildings within the environment both in the city and in the country. According to "Nowoczesne hotelarstwo" (Błądek [5, p. 305]) a hotel understood as a part of tourism is connected with the natural but also man-made environment and Holzberg (in [2, p. 8-9]) connects fine design with natural materials such as wood or stone which helps a building to 'soak' into the natural environment. Ciach et al. [6, p. 20] enriches the list of Polish natural materials by adding clay and straw. Following this statement, it should be emphasized that proper infilling of a new building in both urban and natural landscape is at least as important as its energy-saving and low-waste production parameters. Hotels were chosen as the object of this study because they are a business and commercial enterprise focusing on accumulating maximum income. In order to obtain high profits, costs are optimized as much as possible. On the other hand, due to growing demands of clients and increasing competition, owners encourage choosing their brand by adding new functions and services, rising up standards, refurbishing, renewing interiors and introducing individual character $[7$, p. 5]. Constant development of 
accommodation service market forces its elements to change and transform every day. It brings aliveness to their surroundings but costs, material and energy usage are high. These opposite tendencies create a specific balance in hotel management, which reminds ecosystem activity. The hotel objects erected in the last ten years, i.e. from 2002 to 2012 mainly in Poland were taken into account with a special focus on Wroclaw due to its especially interesting examples. For comparison studies a number of foreign hotels of worldwide networks were taken into consideration. Our research comprised about forty examples and for our needs only few of the most accurate representatives were chosen and presented in the section entitled case studies.

The main purpose of the presented studies was to find what qualities stand for an ecological hotel. Research was carried out in order to check how much environment friendly policies are important in Polish hotels and whether their elements are actually realized and if they are very different from those that are working well in other countries. What essentials are different and why? Another aim was to check how a designer can solve facades and material usage in order to preserve and enrich the environment surrounding his building. In the end, general conclusions were formed and presented about those areas of the Polish hotels ecological policies that need to be refined and developed in the nearest future to meet a growing demand for protection of the natural and urban environment.

\section{Discussion}

Firstly, the definition of discussion should be clarified. It was assumed that all of the previously described elements are important so the term ecological hotel is understood as a hotel building that has solutions aimed at limiting its harmful influence on the natural environment or human health and at the same time it is designed as fitting into its surroundings (city or country). A planning process of each building starts from a general analysis of the site and its elements such as existing buildings, installations, green areas, close and far neighborhood, natural lighting and communication system. Advantages and disadvantages of the location are taken into account. Then designers search for the best form in close connection with function, structure, materials and decoration. During this process, both architect and investor's attention is mainly focused on optimization of cost while fulfilling the established program and obtaining the highest parameters of the usable area. Issues of saving energy and creating an environment friendly building seem much less important.

\subsection{Architect's role}

At first glance hotel's eco-friendly policies take into consideration mainly technical infrastructure for obtaining and managing energy, reduction of water usage and optimal management of waste. Crucial savings can be made on properly designed lighting and ventilation systems or carbon dioxide calculation. Literature examples $[1$, p. 5] also point to ways of human resources management 
because in order to create and sustain each workplace a certain amount of energy and materials has to be used. All these elements are strictly connected with facility management and equipment standards and seem to be very remotely related to an actual building design.

However, an architect can contribute significantly by his work from a very early stage of a design concept. Choosing the optimal site - if possible - enables to use renewed energy such as geothermal sources and heating pumps for object heating and solar panels for warming up water used for living purposes. Listed sources are the most popular and usually optimal in Poland; however, in other countries they differ. Wind or water turbines as well as combustion of biomass can be taken into account. Another issue is location of buildings due to obtaining the best daylight for interiors and gaining passive heating energy in winter while avoiding overheating during summer (usually with the use of shading systems or special window glass with solar control coatings). In Poland for the best energysaving conditions [5, p. 305] southern exposure is advised, especially when most of the living zones are well lighted with sun rays during winter. The same factors are considered while shaping a building and modeling each floor plan and façade (e.g. size of windows).

Moreover, a selected type of the building structure and its materials as well as finishing of walls, floors and ceilings can be ecological and fabricated with respect to environment friendly procedures. Careful design should be implied in this process focused on providing the best energy saving solutions by obtaining correct construction of layers of foundations, walls and roofs concerning thermal and water insulation and the avoidance of interlayer water vapour condensation. Furthermore, while solving the architectural detail usually connected with calculation of Bi-directional heat transfer, a designer should reduce the presence of gaps in insulation and lower the percentage of heating escaping through windows and doors, their frames and connections between them as well as walls. Some other usually problematic elements are: wall corners, connections between building and terrain, attics, wreaths, balconies and terraces with their connection to the structure, connection between ceilings and the structure. As the details described above are usually omitted in this part of the project documentation that is demanded by the Polish administration, due to limited demands of the local construction law, it is crucial to plan this element of design at the very beginning of an investment.

\subsection{Systems and technical equipment}

While designing an ecological building an obvious choice seems to be to gain at least part of heating energy from renewable sources. They have been known in architectural design for ages and as Żubrycki [8, p. 92] implies e.g. geothermal sources in forms of hot springs were used by the ancient Romans for building Baths. In literature [5, p. 305] few examples of recommended solutions can be found, namely, ecological solid fuels (e.g. industrial wood waste), photovoltaic panels, solar collectors, heat pumps and much less popular hydrogen cell, water or wind turbine. As a support recuperation can be used to recoup energy form ventilation and air conditioning systems as well as from waste. An optimal solar 
panels configuration can produce about $20-30 \%$ of overall energy in the building in Poland while an average small wind turbine can cover 15-30\% (quantities were given for a typical family house) [8, p. 93]. The main problem of this solution is efficiency, especially during winter when temperatures in Poland can fall to $-22^{\circ} \mathrm{C}$. The described sources help to control carbon dioxide emission which is one of the most crucial elements of environment friendly politics.

One of the most popular solutions implemented lately in hotels is Building Management System (BMI) which allows changing dynamically the parameter of the temperature in rooms depending on whether or not a guest is inside. Standby temperature is usually set on $10-14^{\circ} \mathrm{C}$, while in used interiors it is $20-22^{\circ} \mathrm{C}$ and $24^{\circ} \mathrm{C}$ in bathrooms. After deciding to use this solution, it is very important to design compartments between rooms providing low heat flow. The thermal insulation put between two structure walls acts also as an acoustical barrier, which is a very important element in creating overall hotel comfort. Savings on heating energy are considered to be cost-effective; moreover, BMI will also control artificial lighting intensity, position of the blinds which can be adjusted according to weather station measurements and time of the day, work of air condition and ventilation and any other programmable parameters of electronic equipment and appliances. It is very important to predict the use of such a solution at an early stage of design because implementing it at a finished building will be connected with additional costs. In one of the articles a statement was made [e.g. 5, p. 307] that ventilation and air conditioning systems are responsible for about 30 to $60 \%$ of all energy loses in a hotel. As a good solution to this problem the author suggests using ice water and rotary heat exchangers in the installation in order to lower the aforementioned loses. In the introduction there was a brief reference to the works of Glenn Murcutt whose designs were focused on total elimination of air conditioning from buildings. Elements such as mobile construction of walls allowing their removal, external blinds on facades, glass blinds in mobile ceiling panels for regulating airflow in interiors, shading windows with special frames around them and creating slots for air penetration in surfaces of roofs by special pleated sheet arrangement, were used by the architect in designing family houses [3, p. 25]. Similar ideas based on rules of natural air flow could be implemented in the ecological design of hotels. We could also bring to mind traditional Arabian wind towers or ancient Roman and Greek houses. Their unique design brought cool air in very high exterior temperatures to large inner spaces. Of course all these Mediterranean and Australian ideas cannot be simply implemented into the temperate climate zones; however, if smartly modified, they can be efficient. Avoiding air conditioning that changes parameters of humidity of air, forces a building to be hermetic and when improperly maintained can be a source of diseases, can be a great advantage.

Another element worth analyzing is lighting. Natural lighting was discussed above, but the problem of energy loss is mainly connected with artificial one. This issue is concerned with both interiors (decorative lighting, illumination of rooms, bathrooms, communication, common zones, work places) and exteriors (illumination of facades, gardens, roadways and sidewalks). It is important not 
only to use economical light sources like LEED but also to consider where they are actually needed. Another significant element of this system is to install automatic switches in interiors (can be connected to BMS system) and dusk sensor for exteriors $[1$, p. 6]. Continuing this reasoning, it is important to use energy-saving electronic utilities and appliances preferably emitting heat and noise at a lowest possible level. A Polish document (Eng. Clean Tourism) $[1$, p. 8] also contains information on saving water. It points out that average usage of water per day in a common hotel is $150 \mathrm{l}$, but for the five-star standard it goes up to $250 \mathrm{l}$. According to certificates criteria, at least half of the installed water outlets should have limiting appliances like aerators. Other solutions in this field would be showers designed in place of baths and flushes with two compartments. All these elements help to reduce waste production, which seems to be crucial, particularly in country hotels.

While designing an ecological building it is necessary to take into account costs of the proposed eco-friendly solutions. As Żubrycki [8, p. 92] points out, systems allowing to obtain ecological energy in Poland are about two times more expensive than traditional ones while for amortization of costs investors have to wait from 5 to 20 years. After that time, an investment should bring savings for owners [6, p. 19]. Stelmach et al. [6, p. 20] claims that a public utility building erected as a passive building is only $12 \%$ more expensive than a traditional one. In practice, it is impossible to find passive hotels in Poland, however, many aforementioned energy saving and ecological solutions are already implemented on a small or large scale.

\section{Case study}

Generally in Poland two out of three international certificates for green buildings have been approved: British BREEM (BRE Environmental Assessment Method by the Building Research Establishment - BRE) and American LEED (Leadership in Energy and Environmental Design) [4, p. 100]. In Wroclaw only two of the twenty studied hotels have certificates connected with environment friendly policies and they are different from both of the aforementioned. One is a European program called Green Key and "Hotel Radisson Blu" has this sort of certificate. Another one is called "Clean Tourism" and it is owned by "Radisson Blu" and "Hotel Tumski" in Wroclaw. The latter is a form of confirmation of hotels initiatives but also defines directions of pro-ecological policies and describes their main framework. These elements differ for objects placed in cites and in the country [1, p. 3]. The differences between hotels placed in urban and rural environments designated a division for this paragraph.

\subsection{City hotels}

"Hotel Scandic" as a part of Scandinavian network known for their ecological tradition employ many elements of pro-environmental policies. In one of the articles we can read as follows: [9]: over 11 thousands workers were trained in the field of environmental aspects; 19000 hotel rooms were constructed from 
ecological materials; 114 out of 147 hotels in Nordic countries received Ecolabel certificate [...]; from year 1994 Scandic has reduced water use by $17 \%$, energy by $22 \%$ and carbon dioxide emission by over $38 \%$. In Wroclaw also some smaller initiatives were noticed like designing electric vehicle charging station in the underground car park of local "Scandic Hotel". Another network, known all over the world, namely "Etap Hotel" which is also present in Poland has been conducting an ecological program called "Planet 21 "which consists of several major assumptions and additional commitments. They are aimed at protecting not only guests' health but also workers' health, e.g. by using certified products for interior finishing and cleaning (in 53\% of buildings). In $86 \%$ of hotels energy usage is monitored while water-saving armature and energy-saving light bulbs for all day illumination are installed. Among other initiatives, such actions as the use of renewable energy sources, waste recycling, tree planting or regional food product promotion can be listed [10].

Local media recently wrote a lot about "Flower Hostel" opened in southern Wroclaw district in which interior finishings were produced from materials used for the second time. These recycling ideas were promoted many times over years like temporary library made from plastic bottle cases in Magdeburg or transforming old containers into summer houses by Hybrid Architecture design studio [4, p. 99]. Interestingly enough, the personnel of "Flower Hostel" uses only biodegradable cleaning substances or those that are self-prepared from natural ingredients [11]. Among other actions, water and electricity are saved, garbage is sorted and natural materials are used wherever it is possible. Other hotels also implement some solutions of this sort for the sake of their guests e.g. breakfast based on products coming from certified ecological farms served in "Art Hotel" in Wroclaw. In some objects, efforts are made to decrease chemicals used for cleaning purposes, water treatment in swimming pool and laundry or to propose 3R rule "Reduce, Reuse and Recycle" e.g. packaging in the kitchen and dining area [1, p. 10]. In almost all hotels, guests are asked to use the same towel more than once and in some cases they have garbage bins enabling waste sorting within the room.

A hotel with intelligent systems was recently built in Wroclaw at Włodkowica St. (designed by APA Hubka Studio, erected in 2011). "Hotel Puro" self-service formula is based on computer care over guests and all building elements and systems. Cost reduction and energy saving start at the moment of registration of a client through the Internet website and end with a strict control of air conditioning and heating by the BMS. Traditional registration of guests was replaced by a digital check-in desk where guests can login to their rooms after they arrive. Each room has its own self-service touch panel activated after putting a card-key into the slot near the entrance door. With the use of the panel guests can e.g. adjust the intensity and colour of lighting or air temperature. This helps to avoid overheating or overcooling of the whole hotel while trying to meet the needs of different clients. Self-service breakfast helps to reduce energy that is lost in connection with the need to hire additional staff, prepare meals and do the cleaning. What is worth mentioning is the fact that the whole investment process was previously designed which helped to optimize the construction time which 
lasted only one year. In this way, a negative effect on environment connected with noise and dust produced by the building works was reduced to the necessary minimum. Another aspect of an overall design of "Hotel Puro" is that despite its modern facades glowing at night with colorful LEED light, the whole building fits perfectly into historical context of Włodkowica Street [12]. Although similar energy-saving light solutions were used in "Hotel Ramka" in Poznań (raised in 2012), the building is criticized for its controversial design based on both hightech and baroque inspiration. Apart from that, renewable energy sources providing heating, solar collectors for obtaining warm water and photovoltaic panels for energy ought to be emphasized. In addition, energy loss was reduced by a special glass façade solution. Similarly to Wroclaw "Hotel Scandic", in "Ramka" electrical cars can be charged as well [13].

Both hotels mentioned in the introduction to this paragraph are also involved in the education initiatives. Hotel "Radisson Blu" as part of a large network is a member of the Responsible Business individual program which is directed to employees, guests and citizens. One of the activities within the program is a well known action Clean Up the World. Employees of "Hotel Tumski" are also trained in the field of ecology at an early stage of their work. The entire institution works on the basis of a special instruction for each functional part and group of personnel [1, p. 15]. Education of hotel employees, guests and local communities is a very important element of the whole ecological policy.

\subsection{Country hotels}

According to "Nowoczesne hotelarstwo" (Błądek [5, p. 305]) country hotels are an important element of contact between man and nature. As they are an oasis of peace, their managers should pay attention to protection of landscape and eco-system that surrounds them. Holzberg (in [2, p. 8-9]) stresses that an object of this kind ought to be created on the basis of local materials which can be renewable like wood. While Gwóźdź [4, p. 98] draws our attention to a different understanding of ecological architecture as the one that reduces its negative influence on the natural environment or another that is hidden underground in green terrain or the one that copies a natural form, i.e. so called "bionic".

One of the examples of using a traditional local material is "HOT_elarnia" (erected in 2008, design: BARarchitecture) where the idea of slow life is realized. The hotel and conference complex is situated near the National Park of Wielkopolska. The shape of the building was inspired by the surrounding country houses as well as a thatched roof, walls finished with stone and thick white plaster. In the very modern interior wood and leather were used as a contrast with architectural concrete and glass. Construction pillars covered with genuine tree bark and floors made of old oak planks are bringing interiors closer to nature [14]. Local materials and building solutions such as a thatched roof, old brick, stone, wood and traditional plaster can also be found in "Hotel Remes" built in Opalenica (in 2010) and designed by Design Studio of Janusz Pulikowski. Another even more unique example in this group would be a complex called "Dwór Oliwski" in Gdańsk (finished in 2009) where not only is the entire structure a part of the regional history, but also the buildings 
themselves are a good example of recycling the architectural concept. The traditional approach is often criticized for its lack of innovation and conservatism; however, it must be admitted that the form and environmentfriendly construction of the aforementioned designs increases the values of the surrounding rural context.

Also "Hotel Bukovina" in the Polish mountain town Bukownia Tatrzańska was well composed in its surroundings despite its size and quite modern architecture (erected in 2010, designed by Dariusz Bobakand Krzysztof Martyniak with team, cubature $80000 \mathrm{~m}^{3}$ ). The building consisting of two wings was optically divided into smaller parts resembling traditional mountain houses. Large windows, loggias and glass panels of balustrades created a geometric order of facades while simple details made of wood and finishing of walls and roofs were typical of regional housing. The entrance roof was additionally decorated with sculptured elements. Designers stress that large openings of the building bring interiors closer to nature. In the vicinity of the hotel a large leisure center was erected based on geothermal water sources. The heating system of the building is supplemented by heat pumps. Work of all installations is controlled by BMS. It helps to save up to $30 \%$ of energy needed in comparison with traditional hotels of this size [15]. The example of "Hotel Bukovina" gives a very good contrast with a very negative example of "Hotel Gołębiewski" in Karpacz which is large (area of $116000 \mathrm{~m}^{2}$ ) and disproportional in relation to the surrounding regional buildings [16]. A vast, almost monumental six floor facade rises partially up to seven floors. Two wings starting from a broad central form reminding a stretched mountain cabin end in medieval towers.

Its large size does not necessarily mean that the building cannot fit into the site. The area $\left(112500 \mathrm{~m}^{2}\right)$ similar to "Gołębiewski" has "Vigilius Mountain Resort" situated near Meran in Italy (erected in 2003, designed by Matteo Thunm). Its large capacity has been placed horizontally in a slightly bended two floor building (up to three floors) with facades made from glass and wooden profiles and shades. On the roof the architect designed a garden. He also placed a restaurant in the old granary. In this way, the large capacity has been blended in a hill on which it was erected and penetrated the existing built substance, so it gives a very good positive example of how to design in an ecological way. What is interesting, the only way to access the hotel is by a funicular. In this way, natural surroundings don't suffer from noise and fumes produced by the car. Large windows are intended to obtain sunlight energy for passive support of heating system $[17, \mathrm{p} .132]$.

\section{Summary and conclusions}

Few of the described ecological solutions are already demanded by the Polish construction law for most buildings. A need for each owner to obtain e.g.: energy passports or obligatory preparation of evaluation of environmental impact for the planned investment forces designers to reduce harmful influences of buildings on natural settings and use energy-saving solutions. What is more, technical conditions defined by the Polish construction law requires from architects to re- 
think each designed compartment and calculate risks of occurrence of thermal bridges and interlayer water vapour condensation as a part of projected buildings energy performance. In the same document, paragraphs can be found focusing on prevention of buildings overheating. However, other elements of an environment friendly approach are still up to individual investor's choices and science should bring new ideas closer to the general public. Educational initiatives such as open sessions at conferences, articles in popular press and as well as other forms can be a great help.

In conclusion, it should be emphasized that research in the nearest future ought to be focused on lowering costs of implementing ecological solutions in Poland. Interdisciplinary studies should both develop natural solutions similar to Glenn's Murcutt's ideas and work on increasing the availability of technical equipment. What is more, architects and investors should bear in mind that even small and local initiatives do matter in the overall growth of social awareness of the European ecological problems. Hotels similar to "Fab Lab House" (an experimental building that produces three times more energy than it consumes) will be realized in future, however, what we can do today is to bring smart and efficient ecological solutions to newly erected and renewed buildings.

\section{References}

[1] Czysta Turystyka czyli odpowiedź na potrzeby współczesnego turysty, red. Starowiejska I., wyd. Fundacja Partnerstwodla Środowiska, Kraków 2011.

[2] Cool Hotels. Ecological, ed. Patricia Massó, teNeues Publishing Group, Kempen 2007.

[3] Krzechowicz G., Ekologia i funkcjonalizm, w: "Architektura and Biznes" 02/2012, p. 25.

[4] Gwóźdź E., Ekologia w architekturze i budynki zielone, w: "świat architektury" 6(13)/2012, pp. 98-100.

[5] Nowoczesne hotelarstwo. Od projektowania do wyposażenia, red. Błądek Z., Oficyna Wydawniczo-Poligraficzna Adam, Warszawa 2010.

[6] Ciach Sz., Jabłońska J. Pyszczek T., Stelmach M., Architektura Pasywna. Wywiad z Tomaszem Pyszczkiem i Marcinem Stelmachem., w: "świat architektury" 6(13)/2012, pp. 98-100.

[7] Hotel Design, red. Josep Minguet, ed. Instituto Monsa de Ediciones S.A., Barcelona.

[8] Żubrycki R., Odnawialne źródła energii w architekturze. Budownictwo indywidualne., w: „świat architektury” 6(13)/2012, pp. 92-95.

[9] Działalność sieci oparta na ochronie środowiska. Grupa Scandic z nagrodą za działalność ekologiczną. http://www.horecanet.pl, 03.01.2012 (access: 03.05.2012).

[10] http://www.etaphotel.com (access: 03.07.2012).

[11] http://www.flowerpowerhostel.pl/ekoLOGICZNIE/14 (access: 14.05.2012).

[12] Ciach Sz., Jabłońska J., Berndt B., Dudek I., Kłak P., Puro. Inteligentny hotel we Wrocławiu., "świat architektury" 6(13)/2011, pp. 32-40. 
[13] http://www.hotelnews.pl/w-lipcu-ruszy-w-poznaniu-hotel-ramka/ (access: 04.07.2012).

[14] Konieczny B., Design pod strzechą. Projekt hotelu w Puszczykowie, w: „świat architektury” 2/2012, pp. 40-43.

[15] Bobak D., Martyniak K., Hotel Bukovina, w: "świat architektury" 7(14)/2011, pp. 73-74.

[16] http://bryla.gazetadom.pl/bryla/1,85301,9435500,2_Moloch_u_stop_Sniez ki hotel_Golebiewski_w_Karpaczu_,ga,,2.html (access: 14.05.2012).

[17] Vickers G., 21st century hotel, Laurence King Publishing, London 2005. 